\title{
Tingkat Kecanduan Internet pada Remaja Awal
}

\author{
Ayu Permata Sari ${ }^{1}$, Asmidir Ilyas ${ }^{2}$, Ifdil Ifdil ${ }^{3}$ \\ ${ }^{123}$ Universitas Negeri Padang
}

\begin{abstract}
This study shows that there are students who have an Internet addiction. Addictions possessed by students will certainly have a negative impact on self, social relationships and learning outcomes. This study aims to describe: 1) The level of Internet addiction in general 2) The core symptoms of Internet addiction in early adolescents 3) Problems related to Internet addiction in early adolescence. Quantitative research method with the quantitative descriptive approach. The population of this study is 596 students of SMA N 7 Padang and a sample of 240 students selected by proportional random sampling technique. The results revealed: 1) The rate of internet addiction in early adolescence is generally mostly in the moderate category with a percentage of $50 \%, 2$ ) The core symptoms of Internet addiction in early adolescence are mostly in the high category with a percentage of $43 \%$, consisting of indicators of compulsive symptoms, withdrawal symptoms and tolerance symptoms. 3) Internet-related addiction problems in early adolescence were mostly in the moderate category with a $49 \%$ percentage consisting of two interpersonal indicators \& health problems and time management problems.
\end{abstract}

Keywords: addiction, internet, counseling

This is an open access article distributed under the Creative Commons Attribution License, which permits unrestricted use, distribution, and reproduction in any medium, provided the original work is properly cited. @ 2017 by author and Indonesian Institute for Counseling, Education and Therapy (IICET).

\section{PENDAHULUAN}

Masa remaja merupakan periode dimana individu meninggalkan masa anak-anak memasuki masa dewasa. Oleh sebab itu periode remaja dapat dikatakan periode masa transisi dari masa anak-anak ke masa dewasa. Pada masa ini individu banyak mengalami tantangan dalam proses perkembangan, baik dari dalam diri maupun dari luar terutama lingkungan sosial (Prayitno, 2006).

Secara psikologis masa remaja merupakan masa untuk berintegrasi dengan orang disekitarnya. Pada masa ini remaja tidak lagi merasa di bawah tingkat orang yang lebih tua tetapi berada dalam tingkatan yang sama, terutama dalam masalah hak (Hurlock, 1980). Menurut pakar psikologi, yang dimaksud dengan remaja adalah individu yang berada pada rentangan umur antara 13 sampai 21 tahun. Sedangkan awal masa remaja bermula dari umur 13 tahun sampai 16 atau 17 tahun dan akhir masa remaja berawal dari 17 tahun sampai 18 tahun (Hurlock, 1980).

Pada periode ini, individu tidak hanya dituntut untuk bersosialisasi dengan keluarga, namun juga dengan masyarakat sehingga individu dapat berbaur dan menyesuaikan diri dengan norma yang berlaku dimasyarakat (Prayitno, 2006).

Masa remaja ditandai dengan perubahan-perubahan diantaranya kebutuhan untuk beradaptasi dengan perubahan fisik dan psikologis, pencarian identitas diri serta membentuk hubungan baru (Santrock, 1998). Menurut Prayitno (dalam Utami, Ahmad, R \& Ifdil, 2017), pada periode ini individu tidak hanya dituntut untuk bersosialisasi dengan keluarga, namun juga dengan masyarakat sehingga individu dapat berbaur dan menyesuaikan diri dengan norma yang berlaku dimasyarakat. Sejalan dengan perubahan-perubahan yang terjadi pada diri remaja, remaja juga dihadapkan pada tugas-tugas perkembangan yang harus dipenuhinya. Apabila tugas-tugas perkembangan tersebut bisa dijalankan dengan baik, maka akan tercapai suatu kepuasan, kebahagiaan dan penerimaan dari lingkungan.

Keberhasilan remaja dalam menjalani tugas-tugas perkembangan tersebut akan berpengaruh pada keberhasilan remaja untuk memenuhi tugas perkembangan pada fase berikutnya (Retnowati, 2016). Namun, 
tidak semua remaja mampu memenuhi tugas-tugas perkembangan tersebut dengan baik. Di era globlalisasi saat ini, perkembangan remaja banyak yang tidak sesuai dengan tugas-tugas perkembangannya. Ini disebabkan karena banyak faktor, salah satunya kemajuan ilmu pengetahuan dan teknologi (Ameliola \& Nugraha, 2013).

Kemajuan ilmu pengetahuan dan teknologi saat ini sangat merajalela di kalangan masyarakat terutama di kalangan remaja. Teknologi informasi yang sering digunakan oleh remaja seperti telepon seluler, video call, media sosial dan berbagai situs penghubung seperti facebook yang sangat membantu sebagai alat multifungsi, karena multifungsi tersebut remaja banyak menggunakan teknologi secara positif maupun negatif (Ma'rifatul Laili \& Nuryono, 2015).

Selain itu, teknologi informasi dan komunikasi yang sangat berkembang pesat saat ini ialah internet (Ameliola \& Nugraha, 2013). Internet tidak hanya sekedar teknologi untuk berbagi data, tetapi juga menyediakan berbagai situs seperti jejaring sosial (path, twitter dan line) yang saat ini sangat populer di kalangan remaja. Internet merupakan kemajuan teknologi informasi dan komunikasi yang memberikan peluang untuk memperoleh informasi dengan cepat, tepat dan terjangkau. Oleh karena itu, internet sangat memudahkan para penggunanya terutama pada remaja.

Penggunaan internet bisa dilakukan dengan faktor pendukung, seperti komputer, notebook atau melalui telepon seluler. Penggunaan internet oleh remaja dapat memberikan dampak positif maupun negatif, hal ini terjadi karena remaja cenderung mudah terpengaruh oleh lingkungan sosial tanpa mempertimbangkan efek yang akan diterima saat melakukan aktivitas internet (Dharmawan, 2012).

Dampak positif yang ditimbulkan oleh internet antara lain untuk memudahkan surat menyurat, mengirim pesan, chatting, mengambil atau mengirim informasi dan sarana untuk hiburan (Fauziawati, 2015). Namun pada umumnya remaja tidak mampu memfilter hal-hal baik ataupun buruk dari internet tersebut, sehingga remaja rentan terkena dampak negatif dari penggunaannya. Diantara dampak negatif dari penggunaan internet adalah kedisiplinan belajar remaja menurun, muncul stres dan kecemasan, serta kehilangan konsep diri (Reski, Taufik, \& Ifdil, 2017; Barseli, \& Ifdil, I., 2017; Zola, Fadli, \& Ifdil, I., 2018; Annisa, \& Ifdil, I., 2016; Alizamar, et al., 2018; Thanoesya, Syahniar, \& Ifdil, I., 2016)

Pada tahap perkembangannya, remaja berada pada tahap krisis identitas, cenderung mempunyai rasa ingin tahu yang tinggi, selalu ingin mencoba hal-hal baru, mudah terpengaruh oleh teman-teman sebayanya (Sarwono, 2004). Individu yang memiliki rasa ingin tahu yang tinggi pada umumnya memiliki kepercayaan diri yang tinggi dan bebas untuk menyatakan pikiran, perasaan dan kreatif. Sedangkan individu yang memiliki keingintahuan yang rendah menunjukkan ciri-ciri kurang percaya diri, merasa tidak aman, tidak dapat mengekspresikan pikiran dan perasaan secara bebas (Ifdil, 2010). Namun tidak sedikit remaja yang terkena dampak negatif dari penggunaan internet, salah satu dampaknya remaja menjadi sangat tergantung pada pengaksesan internet untuk mencapai kepuasan dengan menghabiskan waktu berlarut-larut, sehingga remaja mengalami kecanduan (Fauziawati, 2015).

Kecanduan merupakan suatu keterlibatan secara terus-menerus dengan sebuah aktivitas meskipun hal-hal tersebut mengakibatkan konsekuensi negatif (Ma'rifatul Laili \& Nuryono, 2015). Pada kesempatan ini, kenikamatan dan kepuasanlah yang awalnya dicari, namun perlu keterlibatan selama beberapa waktu dengan aktivitas itu agar seseorang merasa normal. Seseorang yang mengalami kecanduan pada internet dapat menggunakannya dalam waktu yang lama.

Seseorang bisa dikatakan kecanduan internet jika penggunaannya bisa lebih dari tiga puluh menit dalam sehari atau jika dilihat dari frekuensinya maka penggunaannya bisa lebih dari tiga kali dalam sehari (Ma'rifatul Laili \& Nuryono, 2015). Sedangkan menurut penelitian yang dilakukan oleh Markeeters pada tahun 2013, hampir $70 \%$ pengguna internet di Indonesia berusia lima belas sampai usia dua puluh dua tahun menghabiskan waktu lebih dari tiga jam sehari menggunakan internet. Tiga hal utama yang dilakukannya adalah mengakses media sosial 94\%, mencari info 64\% dan membuka email 60,2\% (Santika, 2015).

Penelitian yang dilakukan oleh Agusta (2016) tentang faktor-faktor resiko kecanduan menggunakan smartphone pada siswa SMK N 1 Kalasan Yogyakarta, mengungkapkan bahwa: 1) faktor internal merupakan faktor yang paling beresiko menyebabkan kecanduan yang terdiri dari aspek kontrol diri yag rendah, sensation seeking yang tinggi dan self esteem yang rendah, 2) faktor situasional merupakan faktor kedua yang beresiko, terdiri dari aspek tentang situasi psikologis individu, 3) faktor eksternal merupakan faktor ketika yang beresiko, 
terdiri dari aspek tentang pemaparan media yang tinggi terhadap smartphone, 4) faktor sosial merupakan faktor keempat yang beresiko, terdiri dari aspek tentang interaksi sosial siswa.

Selanjutnya penelitian yang dilakukan oleh Arisandy (2009) tentang hubungan antara kontrol diri dengan kecanduan internet pada mahasiswa Universitas Bina Darma tahun 2009 Palembang, ada hubungan negatif antara kecanduan internet dengan kontrol diri pada mahasiswa Universitas Bina Darma Palembang. Hal ini berarti bahwa semakin tinggi kecanduan internet maka semakin rendah tingkat kontrol diri, sebaliknya semakin rendah kecanduan internet maka semakin tinggi tingkat kontrol diri. Besarnya sumbangan efektif yang diberikan oleh variabel kontrol diri untuk kecanduan internet adalah sebesar 17,8\%.

Penelitian yang dilakukan oleh Qomariyah (2013) tentang perilaku penggunaan internet pada kalangan remaja di perkotaan, memaparkan kalangan remaja diperkotaan menggunakan internet untuk empat dimensi kepentingan, yaitu informasi, aktivitas kesenangan, komunikasi dan transaksi. Meskipun dari keempat kepentingan penggunaan internet tersebut, aktivitas-aktivitas internet yang dilakukan kalangan remaja di perkotaan lebih banyak untuk aktivitas kesenangan daripada untuk kepentingan lainnya.

Kemudian penelitian yang dilakukan oleh Basri (2014)tentang kecenderungan internet addiction disorder mahasiswa fakultas dakwah dan komunikasi ditinjau dari religiositas, mendeskripsikan bahwa ada hubungan yang signifikan dan negatif antara religiositas dan kecenderungan internet addiction disorder. Hasil perbandingan hipotesa dengan uji $\mathrm{t}$ menunjukkan bahwa terdapat perbedaan dilihat dari jenis kelamin. Perbandingan tingkat religiositas pada mahasiswa perempuan lebih tinggi daripada laki-laki dengan skor 70,04 untuk pria dan 71,04 untuk perempuan. Hasil derajat perbandingan kecenderungan internet addiction disorder menunjukkan bahwa laki-laki 63,76 dan 66,09 untuk perempuan. Berdasarkan hasil perbandingan tersebut, perempuan memiliki kecenderungan internet addiction disorder lebih tinggi dari laki-laki.

Berdasarkan temuan penelitian dapat disimpulkan, kecanduan merupakan kondisi terikat pada kebiasaan yang sangat kuat dan individu tidak mampu lepas dari kebiasaan itu. Kecanduan internet juga merupakan suatu kelainan yang muncul pada individu yang merasa bahwa dunia maya pada layar komputernya lebih menarik daripada dunia nyata. Seseorang yang kecanduan akan merasa terhukum apabila tidak memenuhi hasrat kebiasaannya.

Kenyataan yang ditemukan di SMA Negeri 7 Padang, ada beberapa remaja yang menghabiskan waktu berjam-jam untuk mengakses internet, tidak fokus saat mengikuti pelajaran, suka menunda-nunda pekerjaan, kurang berinteraksi sosial dengan sesama, bersikap autis terhadap lingkungan serta rela meninggalkan kewajiban demi mengakses internet. Kemudian hasil wawancara yang dilakukan dengan siswa, rata-rata siswa mengakses internet untuk membuka media sosial, bermain game online dan mendownload berbagai situs.

Informasi lebih lanjut juga diperoleh dari guru BK SMA Negeri 7 Padang, bahwa siswa seringkali bermasalah dan diproses karena ketahuan sedang menggunakan ponsel dan mengakses internet, seperti bermain game online dan chating dalam jam pelajaran. Tidak jarang guru-guru menegur dan memberikan sanksi kepada siswa yang bermasalah, namun hal tersebut tidaklah membuat siswa jera. Padahal dengan terganggunya konsentrasi belajar siswa karena kesenangan mengakses internet, membuat siswa mengalami banyak permasalahan dalam pembelajaran, salah satunya ialah kesulitan mengikuti pelajaran dan dapat berdampak pada rendahnya prestasi belajar siswa di sekolah.

Kecanduan pada remaja ini harus dientaskan, jika tidak maka akan membawa dampak buruk untuk perkembangan remaja kedepannya. Remaja merupakan salah satu pengguna internet yang justru belum mampu memilah aktivitas internet yang bermanfaat, mereka cenderung mudah terpengaruh oleh lingkungan sosial tanpa mempertimbangkan terlebih dahulu efek positif atau negatif yang akan diterima saat melakukan aktivitas internet (Qomariyah, 2013).

Seseorang yang kecanduan internet akan kesulitan mengembangkan kemampuan atau kecakapannya dalam berhubungan dengan orang lain sehingga membuat hubungan sosial dan interaksi mereka dengan keluarga, teman dan orang disekitarnya menjadi kurang baik serta mengalami prestasi akademik yang menurun (Jannah, Mudjiran, \& Nirwana, 2015). Remaja yang kecanduan internet dapat mengalami gangguan panik, stress (Wardi, \& Ifdil, 2016; Barseli, Ifdil, \& Nikmarijal., 2017; Zola, Fadli, \& Ifdil., 2018) dan anxiety (Annisa, \& Ifdil, 2016).

Berdasarkan hal tersebut, tugas perkembangan remaja menjadi tidak sesuai dengan tahap-tahap perkembangan yang semestinya. Kemungkinan besar remaja akan mengalami ketidakpercayaan diri dan lain 
sebagainya. Ketidakpercayaan diri ini akan membuat keyakinan dalam jiwa remaja bahwa tantangan hidup apapun yang dihadapi akan terasa sulit jika tidak berbuat sesuatu (Ifdil, Denich, A. U \& Ilyas, A, 2017; Fitri, E., Zola, N., \& Ifdil, I., 2018). Ketidaksingkronan kondisi yang terjadi pada tugas perkembangan remaja saat ini harusnya dientaskan. Upaya pengentasan bisa dilakukan oleh siapa saja, mulai dari diri sendiri, teman, guru, orangtua maupun guru BK/konselor. Dalam pengentasan kecanduan internet pada remaja, orangtua bisa membuat jadwal kapan anak bisa menggunakan komputer atau telepon seluler. Dengan begitu anak tidak akan melupakan kewajibannya yang lain, terutama belajar (Susilo, 2010).

Selain itu guru BK/konselor juga dapat berperan dalam pengentasan yang dilakukan untuk menurunkan tingkat kecanduan yang dialami oleh remaja. Guru BK/konselor merupakan seorang pendidik yang ditugaskan untuk memandirikan siswa, mengembangkan potensi diri siswa dan membantu siswa dalam mengentaskan masalah-masalah yang dialaminya baik di lingkungan sekolah maupun di lingkungan luar sekolah (Sandra, R \& Ifdil). Tatalaksana pengentasan ini dapat mencakup perubahan gaya hidup remaja melalui pelaksanaan konseling dengan berbagai layanan, salah satunya dengan konseling individual menggunakan teknik rasional emotif terapi dan konseling kelompok dengan pendekatan Cognitif Behavior Teraphy (Fitri, Erwinda, L \& Ifdil). Konseling merupakan salah satu faktor yang mendukung dalam penanganan suatu masalah, dalam konseling nantinya konselor membantu remaja untuk meningkatkan pemahaman serta mendorong untuk membuat penyelesaian terhadap masalahnya, selain itu dengan dilakukannya konseling agar terjadi perubahan perilaku remaja menjadi gaya hidup sehat (Rifit, 2011).

Tujuan yang hendak dicapai pada penelitin ini adalah mendeskripsikan: 1) tingkat kecanduan internet pada remaja awal secara umum, 2) tingkat kecanduan internet pada remaja awal berdasarkan gejala inti kecanduan internet, 3) tingkat kecanduan internet pada remaja awal berdasarkan masalah terkait kecanduan internet.

\section{METODE PENELITIAN}

Penelitian ini bersifat deskriptif kuantitatif untuk mendeskripsikan secara sistematis, faktual dan akurat mengenai fakta-fakta dari sifat-sifat populasi atau mencoba menggambarkan fenomena secara detail. Dengan demikian, penelitian ini mengungkapkan tingakti kecanduan internet pada remaja awal di SMA Negeri 7 Padang, dengan jumlah subjek 240 orang. Instrumen penelitian yang digunakan adalah kuesioner medel skala likert. Data yang diperoleh dianalisis dengan menggunakan teknik persentase.

\section{HASIL DAN PEMBAHASAN}

Berdasarkan hasil pengolahan data yang telah dilakukan, hasil penelitian disajikan dan dianalisis sesuai dengan tujuan penelitian yang diajukan sebelumnya, yaitu mendeskripsikan: 1) tingkat kecanduan internet pada remaja awal secara umum, 2) tingkat kecanduan internet pada remaja awal berdasarkan gejala inti kecanduan internet, 3) tingkat kecanduan internet pada remaja awal berdasarkan masalah terkait kecanduan internet.

\section{Tingkat Kecanduan Internet Pada Remaja Awal Secara Umum}

Berdasarkan hasil penelitian yang dilakukan, tingkat kecanduan internet pada remaja awal di SMA Negeri 7 Padang dapat dilihat pada tabel berikut ini:

Tabel 1. Tingkat Kecanduan Internet Pada Remaja Awal Secara Umum

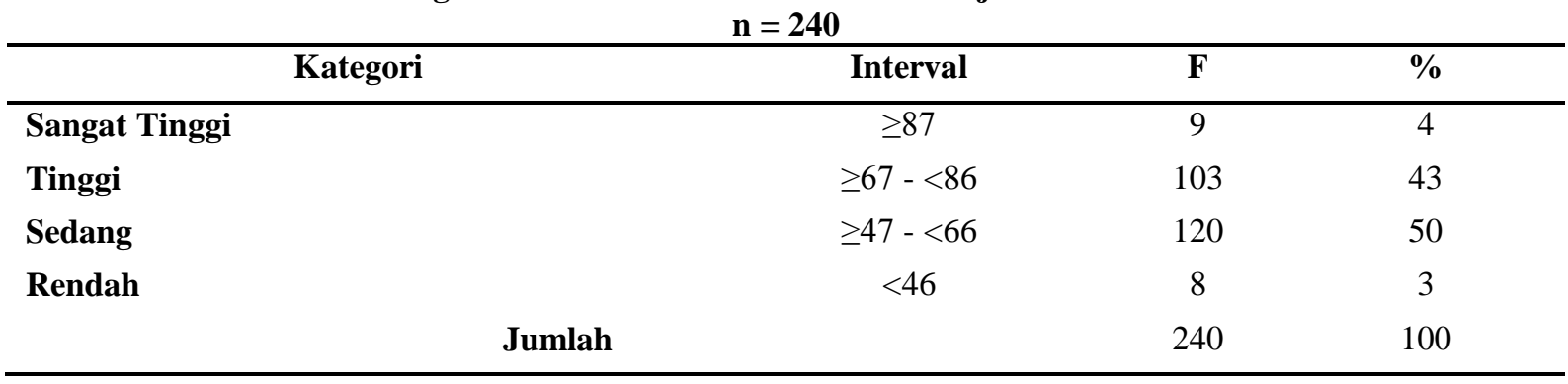

Berdasarkan tabel satu, dapat dilihat secara keseluruhan tingkat kecanduan internet pada remaja awal, sebanyak sembilan orang siswa (4\%) sebagian besar berada pada kategori sangat tinggi, seratus tiga orang siswa 
(43\%) sebagian besar berada pada kategori tinggi, seratus dua puluh orang siswa $(50 \%)$ sebagian besar berada pada ketegori sedang dan delapan orang siswa (3\%) sebagian besar berada pada kategori rendah.

\section{Gejala Inti Kecanduan Internet Pada Remaja Awal}

Berdasarkan hasil penelitian yang dilakukan, tingkat kecanduan internet pada remaja awal di SMA Negeri 7 Padang dapat dilihat pada tabel berikut ini:

Tabel 2. Gejala Inti Kecanduan Internet Pada Remaja Awal

\begin{tabular}{|c|c|c|c|}
\hline Kategori & Interval & $\mathbf{F}$ & $\%$ \\
\hline Sangat Tinggi & $\geq 48$ & 17 & 7 \\
\hline Tinggi & $\geq 37-<47$ & 104 & 43 \\
\hline Sedang & $\geq 26-<36$ & 101 & 42 \\
\hline Rendah & $\leq 25$ & 18 & 8 \\
\hline \multicolumn{2}{|c|}{ Jumlah } & 240 & 100 \\
\hline
\end{tabular}

Berdasarkan tabel dua dapat dilihat bahwa gejala inti kecanduan internet pada remaja awal, sebanyak tujuh belas orang siswa (7\%) sebagian besar berada pada kategori sangat tinggi, seratus empat orang siswa (43\%) sebagian besar berada pada kategori tinggi, seratus satu orang siswa (42\%) sebagian besar berada pada kategori sedang dan delapan belas orang siswa (8\%) sebagian besar berada pada kategori rendah. Dari pemaparan tersebut, secara keseluruhan gejala inti kecanduan internet pada remaja awal sebagian besar berada pada kategori tinggi. Tingkat kecanduan internet pada remaja awal berdasarkan gejala inti kecanduan internet dapat dilihat dalam tiga indikator, yaitu:

\section{Compulsive Symptoms (gejala kompulsif)}

Compulsive Symptoms terjadi ketika penggunaan internet menjadi aktivitas yang paling penting dalam kehidupan individu, mendominasi pikiran individu, perasaan dan tigkah laku (Fatmalisa, 2014). Selanjutnya individu yang mengalami kecanduan biasanya perhatiannya selalu terpukau hanya untuk memikirkan aktivitas online (Chou, Condron, \& Belland, 2005).

Kondisi ini mengungkapkan penggunaan internet mempengaruhi aktivitas, perasaan dan perhatian penggunanya untuk memikirkan aktivitas online. Sebagian siswa yang kecanduan internet juga mengalami kesulitan berkonsentrasi ketika belajar, munculnya perasaan gelisah ketika tidak menggunakan internet, kurang memperhatikan kebutuhan-kebutuhan pribadi dan kesehatan.

Individu yang kecanduan internet akan lebih tertarik menggunakan internet daripada melakukan kegiatan lainnya. Jadi compulsive symptoms merupakan gejala yang mempengaruhi diri individu, mulai dari perasaan, pikiran hingga perbuatan.

Berdasarkan hasil penelitian, terungkaptingkat kecanduan internet pada remaja awal berdasarkan indikator compulsive symptoms sebagian besar berada pada kategori sedang, hal itu ditunjukkan dari 240 orang siswa yang diteliti, 122 orang siswa diantaranya memiliki gejala kompulsif yang berada pada kategori sedang dan hanya 41 orang siswa yang gejala kompulsifnya dikategorikan rendah.

\section{Withdrawal Symptoms (gejala penarikan)}

Withdrawal symptoms merupakan perasaan yang tidak menyenangkan yang terjadi karena penggunaan internet dikurangi atau tidak dilanjutkan, sehingga berpengaruh pada fisik dan psikologis individu itu sendiri (Fatmalisa, 2014). Pengaruh fisik yang sering terjadi seperti pusing dan insomnia. Sedangkan pengaruh psikologisnya seperti mudah marah dan moodiness.

Berdasarkan pemaparan tersebut, dapat disimpulkan withdrawal symptoms merupakan suatu gejala yang mendatangkan ketidakpuasan pada individu jika tidak menggunakan internet. Pemasalahan yang terkait yaitu seperti adanya siswa yang merasa sedih, tidak nyaman dan mudah marah ketika tidak menggunakan internet. 
Hasil penelitian mengungkapkan tingkat kecanduan internet pada remaja awal berdasarkan indikator withdrawal symptoms sebagian besar berada pada kategori sedang, hal itu ditunjukkan dari 240 orang siswa yang diteliti, 118 orang siswa diantaranya memiliki gejala penarikan yang berada pada kategori sedang dan hanya 20 orang siswa yang gejala penarikannya dikategorikan rendah.

\section{Tolerance Symptoms (gejala toleransi)}

Tolerance symptoms merupakan proses dimana terjadinya peningkatan jumlah pengguna internet untuk mendapatkan hasil yang menyenangkan ketika menggunakan internet (Fatmalisa, 2014). Pada kesempatan ini, kenikmatan dan kepuasanlah yang pada awalnya dicari namun perlu keterlibatan selama beberapa waktu dengan aktivitas itu agar seseorang merasa normal (Rahayuning, 2009).

Kepuasan yang diperoleh ketika menggunakan internet secara terus-menerus dalam jumlah waktu yang sama akan menurun secara mencolok sehingga individu berangsur-angsur harus meningkatkan waktu penggunaan internet. Jadi tolerance symptoms merupakan suatu gejala yang menimbulkan adanya keinginan yang kuat pada individu untuk meningkatkan jumlah waktu penggunaan internet guna mencapai kepuasan.

Berdasarkan hasil penelitian yang dilakukan, tingkat kecanduan internet pada remaja awal berdasarkan indikator tolerance symptoms sebagian besar berada pada kategori tinggi, hal itu ditunjukkan dari 240 orang siswa yang diteliti, 131 orang siswa diantaranya memiliki gejala toleransi yang berada pada kategori tinggi dan hanya 3 orang siswa yang gejala toleransinya dikategorikan rendah.

\section{Masalah Terkait Kecanduan Internet Pada Remaja Awal}

Berdasarkan hasil penelitian yang dilakukan, tingkat kecanduan internet pada remaja awal di SMA Negeri 7 Padang dapat dilihat pada tabel berikut ini:

Tabel 3. Masalah Terkait Kecanduan Internet Pada Remaja Awal $\mathrm{n}=\mathbf{2 4 0}$

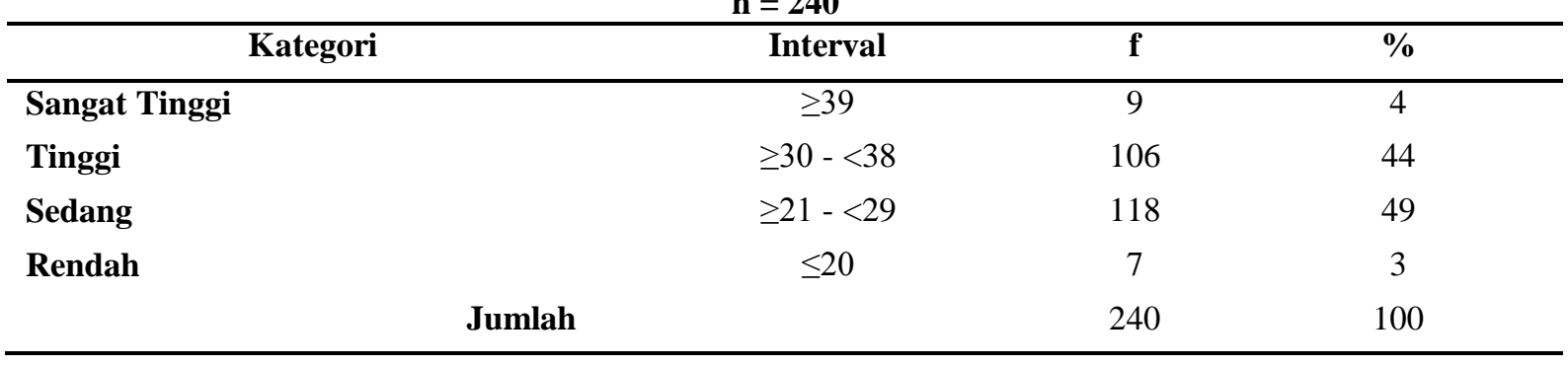

Berdasarkan tabel tiga, dapat dilihat gejala inti kecanduan internet pada remaja awal, sebanyak sembilan orang siswa (4\%) sebagian besar berada pada kategori sangat tinggi, seratus enam orang siswa (44\%) sebagian besar berada pada kategori tinggi, seratus delapan belas orang siswa (49\%) sebagian besar berada pada kategori sedang dan tujuh orang siswa (3\%) sebagian besar berada pada kategori rendah. Dari pemaparan tersebut, secara keseluruhan masalah terkait kecanduan internet pada remaja awal sebagian besar berada pada kategori sedang. Tingkat kecanduan internet pada remaja awal berdasarkan masalah terkait kecanduan internet dapat dilihat dalam dua indikator, yaitu:

\section{Interpersonal \& Health Problem (masalah antarpribadi dan kesehatan)}

Penggunaan internet yang berlebihan dapat mengakibatkan terjadinya masalah pribadi, keluarga dan pekerjaan (Rodgers, 1998). Penggunaan internet yang berlebihan juga dapat memicu munculnya permasalahan lainnya yang membuat KES (kehidupan efektif sehari-hari) menjadi terganggu.

Pemanfaatan internet yang berlebihan mengakibatkan hubungan dengan teman dan keluarga menjadi renggang karena waktu yang digunakan untuk kumpul bersama menjadi jauh berkurang, sehingga remaja menjadi terisolir dari teman-teman dan keluarganya, serta menjadi sulit berkonsentrasi terhadap pelajaran di sekolah. Jadi, interpersonal \& health problem merupakan permasalahan yang dapat terjadi antara diri individu maupun dengan orang lain.

Berdasarkan hasil penelitian yang dilakukan, terungkap tingkat kecanduan internet pada remaja awal berdasarkan indikator interpersonal \& health problem sebagian besar berada pada kategori tinggi, hal itu 
ditunjukkan dari 240 orang siswa yang diteliti, 117 orang siswa diantaranya memiliki masalah antarpribadi dan kesehatan yang berada pada kategori tinggi dan hanya 2 orang siswa yang masalah antarpribadi dan kesehatannya dikategorikan rendah.

\section{Time Management Problem (masalah pengaturan waktu)}

Penggunaan internet yang berlebihan terjadi karena manajemen waktu yang buruk membuat pengguna internet mudah lupa waktu ketika online (Rodgers, 1998). Individu yang memperlihatkan gejala kecanduan internet akan mengarah pada masalah mental emosional, di antaranya dapat menyebabkan distorsi waktu, kurang perhatian, hiperaktif dan lain sebagainya (Fitri, E, Erwinda, L \& Ifdil, 2018). Selanjutnya, dari hasil penelitian Brenner, 80\% dari 600 responden menunjukkan setidaknya ada lima masalah yang berhubungan dengan penggunaan internet, seperti kegagalan untuk mengatur waktu, tidak tidur, tidak makan dan lain-lain. Jadi, time management problem merupakan masalah yang dialami individu untuk mengatur waktu saat menggunakan internet.

Berdasarkan hasil penelitian yang dilakukan, terungkap tingkat kecanduan internet pada remaja awal berdasarkan indikator time management problem sebagian besar berada pada kategori sedang, hal itu ditunjukkan dari 240 orang siswa yang diteliti, 119 orang siswa diantaranya memiliki masalah pengaturan waktu yang berada pada kategori sedang dan hanya 29 orang siswa yang masalah pengaturan waktunya dikategorikan rendah.

\section{KESIMPULAN}

Berdasarkan hasil penelitian dan pembahasan yang telah dipaparkan pada Bab IV mengenai tingkat kecanduan internet pada remaja awal di SMA N 7 Padang, dapat disimpulkan sebagai berikut: 1) Tingkat kecanduan internet pada remaja awal secara umum sebagian besar berada pada kategori sedang dengan persentase $50 \%$, 2) Gejala inti kecanduan internet pada remaja awal sebagian besar berada pada kategori tinggi dengan persentase $43 \%$, terdiri dari indikator compulsive symptoms, withdrawal symptoms dan tolerance symptoms, 3) Masalah terkait kecanduan internet pada remaja awal sebagian besar berada pada kategori sedang dengan persentase $49 \%$ terdiri dari dua indikator interpersonal \& health problem dan time management problem.

Berdasarkan simpulan hasil penelitian, dikemukakan beberapa saran kepada pihak-pihak terkait, yaitu: 1) Bagi guru Bk agar dapat memperhatikan penggunaan internet oleh siswa, 2) Bagi wali kelas diharapkan mampu bekerjasama dengan guru Bk dalam mengawasi penggunaan internet oleh siswa khususnya di sekolah, 3) Bagi kepala sekolah diminta untuk dapat lebih memberikan perhatian besar terhadap penggunaan koneksi internet di sekolah, 4) Bagi peneliti selanjutnya agar bisa mengembangkan studi lain yang berkaitan dengan kecanduan internet pada remaja.

\section{DAFTAR RUJUKAN}

Agusta, D. (2016). Faktor-faktor Resiko Kecanduan Menggunakan Smartphone. E-Journal Bimbingan Dan Konseling, 86-96.

Ameliola, S. \& Nugraha, H. D. (2013). Perkembangan Media Informasi dan Tekonologi Terhadap Anak dalam Era Globalisasi. The 5th International Conference on Indonesian Studies: "Ethnicity and Globalization”ity and Globalization", 362-371.

Annisa, D. F., \& Ifdil, I. (2016). Konsep Kecemasan (Anxiety) pada Lanjut Usia (Lansia). Konselor, 5(2), 93-99.

Arisandy, D. (2009). Hubungan Antara Kontrol Diri Dengan Kecanduan Internet Pada Mahasiswa Universitas Bina Darma Tahun 2009 Palembang.

Basri, A. S. H. (2014). Kecenderungan Internet Addiction Disorder Mahasiswa Fakultas Dakwah Dan Komunikasi Ditinjau dari Religiositas. Jurnal Dakwah, XV(2), 407-432.

Barseli, M., Ifdil, I., \& Nikmarijal, N. (2017). Konsep Stres Akademik Siswa. Jurnal Konseling dan Pendidikan, $5(3), 143-148$

Chou, C., Condron, L., \& Belland, J. C. (2005). A review of the research on Internet addiction. Educational Psychology Review, 17(4), 363-388. https://doi.org/10.1007/s10648-005-8138-1

Dharmawan, P. E. \& A. H. (2012). Dampak Sosial-Ekonomi Masuknya Pengaruh Internet dalam Kehidupan Remaja di Pedesaan. Departemen Sains Komunikasi Dan Pengembangan Masyarakat, Fakultas Ekologi Manusia, IPB.

Fatmalisa, S. (2014). Kecanduan Internet Pada Remaja dan Implikasinya Terhadap Layanan Bimbingan dan 
Konseling. Universitas Negeri Padang.

Fauziawati, W. (2015). Upaya Mereduksi Kebiasaan Bermain Game Online Melalui Teknik Diskusi Kelompok. PSIKOPEDAGOGIA Jurnal Bimbingan Dan Konseling, 4(2), 115-123.

Fitri, E., Erwinda, L., \& Ifdil, I. (2018). Konsep Adiksi Game Online dan Dampaknya terhadap Masalah Mental Emosional Remaja serta Peran Bimbingan dan Konseling. Jurnal Konseling dan Pendidikan, 6(2).

Fitri, E., Zola, N., \& Ifdil, I. (2018). Profil Kepercayaan Diri Remaja serta Faktor-Faktor yang Mempengaruhi. JPPI (Jurnal Penelitian Pendidikan Indonesia), 4(1), 1-5.

Hurlock, E. B. (1980). Psikologi Perkembagan Suatu Pendekatan Sepanjang Rentang Kehidupan. Jakarta: Erlangga.

Ifdil, I. (2010). Pendidikan Karakter dalam Bimbingan dan Konseling. Pedagogi: Jurnal Ilmu Pendidikan, 10(2), 55-61.

Ifdil, I., Denich, A. U., \& Ilyas, A. (2017). Hubungan Body Image dengan Kepercayaan Diri Remaja Putri. Jurnal Kajian Bimbingan dan Konseling, 2(3), 107-113.

Jannah, N., Mudjiran, \& Nirwana, H. (2015). Hubungan Kecanduan Game dengan Motivasi Belajar Siswa dan Implikasinya Terhadap Bimbingan dan Konseling. Konselor, 4(4), 200-207.

Ma'rifatul Laili, F., \& Nuryono, W. (2015). Penerapan Konseling Keluarga Untuk Mengurangi Kecanduan Game Online Pada Siswa Kelas Viii Smp Negeri 21 Surabaya. Jurnal BK, 5(1), 65-72.

Prayitno, E. (2006). Psikologi Perkembangan Remaja. Padang: Angkasa Raya.

Qomariyah, A. N. (2013). Perilaku Penggunaan Internet pada Kalangan Remaja di Perkotaan. Perilaku Penggunaan Internet Pada Kalangan Remaja diPerkotaan, 53(9), 1689-1699. https://doi.org/10.1017/CBO9781107415324.004

Rahayuning, D. D. (2009). Hubungan Antara Kontrol Diri dengan Kecanduan Internet Pada Siswa Sekolah Menegah Pertama (SMP). Universitas Muhammadiyah Surakarta.

Retnowati, S. (2016). Remaja dan Permasalahannya. Fakultas Psikologi UGM.

Rifit, A. (2011). Bimbingan Konseling Islam dengan Terapi Behavior dalam Menangani Kasus Seorang Remaja yang Kecanduan Game Online di Desa Suko Sidoarjo. UIN Sunan Ampel Surabaya.

Rodgers, K. S. Y. \& R. C. (1998). The Relationship Between Depression and Internet Addiction. Cyberpsychology \& Behavior, 1.1, 22-28.

Sandra, R., \& Ifdil, I. (2015). Konsep Stres Kerja Guru Bimbingan dan Konseling. Jurnal EDUCATIO: Jurnal Pendidikan Indonesia, 1(1), 80-85.

Santika, M. G. (2015). Hubungan Antara Fomo (Fear Of Missing Out) dengan Kecanduan Internet (Internet Addiction) Pada Remaja di SMAN 4 Bandung.

Santrock, J. W. (1998). Perkembangan Remaja (Edisi VI, Alih Bahasa: Shinto B. Adelar, dkk). Jakarta: Erlangga.

Sarwono, S. W. (2004). Psikologi Remaja. Jakarta: Grafindo Persada.

Susilo, A. (2010). Teknik Cepat Memahami Keamanan Komputer dan Internet. Jakarta: Elex Media Komputindo.

Taufik, T., Ifdil, I., \& Ardi, Z. (2013). Kondisi Stres Akademik Siswa SMA Negeri di Kota Padang. Jurnal Konseling dan Pendidikan, 1(2), 143-150.

Utami, D. R., Ahmad, R., \& Ifdil, I. (2017). Tingkat Kesepian Remaja di Panti Asuhan X Kota Padang. JURNAL KONSELING GUSJIGANG, 3(1).

Wardi, R., \& Ifdil, I. (2016). Stress Conditions in Students Completing Thesis. GUIDENA: Jurnal Ilmu Pendidikan, Psikologi, Bimbingan dan Konseling, 6(2), 190-194.

Zola, N., Fadli, R. P., \& Ifdil, I. (2018). Chromotherapy to reducing stress. 